\title{
An overview of the biological disease modifying drugs available for arthritic conditions in South Africa
}

\author{
Leonie Harmse, ${ }^{\text {a* }}$ Helmuth Reuter \\ aPharmacology Division, School of Therapeutic Sciences, Faculty of Health Sciences, University of the Witwatersrand \\ ${ }^{b}$ Division of Clinical Pharmacology, Faculty of Medicine and Health Sciences, Stellenbosch University \\ *Corresponding author, email: leonie.harmse@wits.ac.za
}

\begin{abstract}
The past decade has seen a major change in the treatment options and strategies for rheumatoid arthritis (RA) and the other immune-mediated arthritic diseases. The disease modifying antirheumatic drugs (DMARDs) are now used in early stages of the disease in order to preserve joint architecture. There are two groups of DMARDs, the small molecules, like methotrexate, and the biological DMARDs, which are frequently referred to as "magic bullets" since they target specific cytokines and immune cells associated with arthritic conditions. They are monoclonal antibodies or fusion proteins designed to bind and inactivate immune targets.
\end{abstract}

Tumour necrosis factor-alpha (TNF-a) plays an important role in the pathogenesis of rheumatoid disorders and is the target of four biological DMARDs, etanercept, infliximab, golimumab and adalimumab. The other biological DMARDs include abatacept, rituximab and tocilizumab and these prevent T-cell costimulation, cause the depletion of mature CD20 positive B cells or prevent the activation of the interleukin-6 receptor molecule, respectively. Ustekinumab, a monoclonal antibody against IL12/IL23 is effective in psoriatic arthritis.

Biological agents are indicated when patients do not respond adequately to the traditional DMARDs. Numerous clinical trials have shown that the biological agents reduce joint inflammation and erosive damage, especially when used in combination with methotrexate.

Apart from their prohibitive cost, the biological agents are not without potentially serious adverse effects with infections being the main concern. The TNF- $a$ inhibitors increase the risk for tuberculosis and other opportunistic infections, whereas the non-TNF-a immune inhibitors increase the risk for opportunistic viral, fungal and bacterial infections. This review provides an overview of the biological agents currently available in South Africa.

Keywords: TNF- $a$ inhibitors, non-TNF-a biological agents, anti-rheumatic drugs, monoclonal antibodies, fusion proteins, immune modulators

\section{Introduction}

The arthritic diseases are progressive and debilitating and impair the quality of life of patients. It is now common practice to use disease modifying agents early after a diagnosis is made to prevent irreversible joint damage. In recent years the biological DMARDS have been proven to be efficacious against the progression of rheumatoid arthritis (RA) when there is no response or a poor response to traditional DMARDs. ${ }^{1,2}$ An overview of the biological disease modifying agents available for use in South Africa is provided here.

The biological DMARDS are effective when used as single agents but they are seldom used alone, since combinations with methotrexate have been shown to have clinical benefit. ${ }^{2}$ Methotrexate use prevents the formation of antibodies to the biological agents, which extends their therapeutic lifespan.
The prohibitive cost of the biological agents and their costeffectiveness remains an ongoing debate. In this context a recent Cochrane review indicates that methotrexate based small molecule triple therapy may be as efficacious as combinations of biological DMARDs with methotrexate. ${ }^{3}$

\section{What are biological agents?}

Biological DMARDs are protein molecules and include monoclonal antibodies and antibody based fusion proteins. Monoclonal antibodies bind to a specific molecular target, causing inactivation of the target and compete with the natural ligand for binding to the target, thereby preventing the function of the target molecule. Once a monoclonal antibody has associated with its target it triggers the antibody dependent cellular cytotoxic immune response and/or the complement system causing the removal/destruction of the target by the 


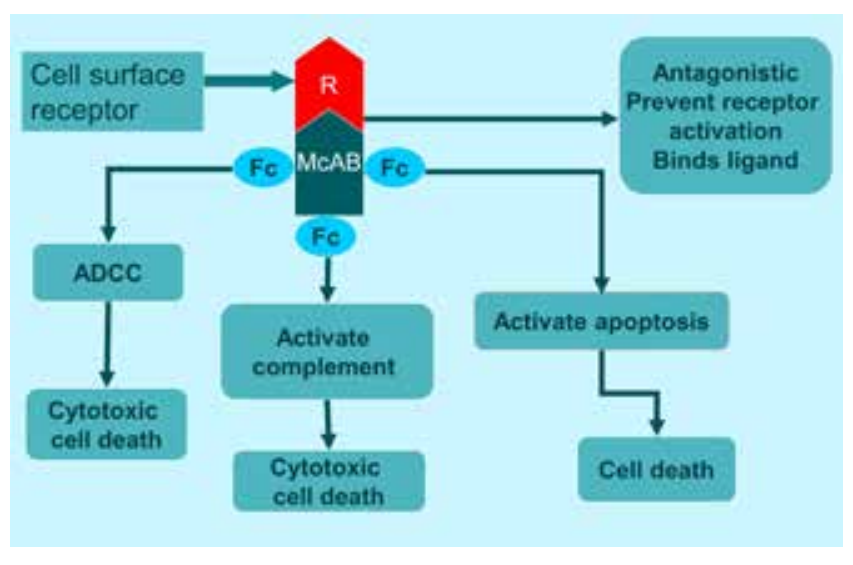

Figure 1. A summary of the consequences of monoclonal antibody binding to its specific receptor molecules. R: antibody specific receptor, McAB: monoclonal antibody, Fc: receptor binding to constant region of a monoclonal antibody, ADCC: antibody dependent cellular cytotoxicity

immune system as shown in Figure 1. In the treatment of the arthritis group of diseases there are two main groups of biological agents available, the tumour necrosis factor- $\alpha$ (TNF- $\alpha$ ) inhibitors and the non-TNF- $\alpha$ inhibitors of the immune system.

\section{TNF- $a$ as a drug target}

TNF-a, a pro-inflammatory cytokine, was identified by Brennan et al in 1989 as an important target molecule in the inflamed synovium of rheumatoid arthritis patients. ${ }^{4}$ Since then clinical trials have proven that a decrease in circulating TNF-a levels decrease disease severity and preserve joint architecture in RA. Clinical trials proved TNF- $\alpha$ inhibitors to have equal efficacy to methotrexate when used alone and superior efficacy when used in combination with methotrexate. In addition, the combined use of TNF- $a$ inhibitors and methotrexate prevents the formation of antibodies to the TNF- $a$ inhibitors. The available TNF- $a$ inhibitors bind to both soluble and membrane bound TNF-a. ${ }^{2,4}$

Adverse effects associated with TNF- $a$ inhibitors are associated with the role of TNF-a in the immune system. Of particular concern is the increased risk of infections, especially with organisms causing the formation of granulomas, like tuberculosis (TB) and histoplasmosis. In South Africa, the high TB burden makes it imperative to screen patients for latent and active infections prior to initiation of TNF-a therapy. It is advisable to immunize prospective patients against influenza, varicella zoster and pneumococcal disease. ${ }^{1}$ In addition, there is an increased risk for fungal viral and other bacterial infections. As with any immunosuppressive regimen, there is always a potential for the development of a malignancy, and patients require careful monitoring. ${ }^{5,6}$

The use of TNF-a inhibitors has been associated with a spectrum of cutaneous reactions. Skin lesions range from injection site reactions to infections that are directly related to immune suppression, like bacterial cellulitis and Herpes zoster. Skin neoplasms and a host of immune mediated cutaneous diseases ranging from psoriasis to vasculitis and pemphigus are associated with TNF-a inhibition. ${ }^{7}$
TNF- $a$ is secreted by monocytes, macrophages, T cells, B cells and fibroblasts and is important to the normal immune response. It is essential for both the formation and maintenance of granulomas in mycobacterial infections, explaining why latent infections are reactivated in patients treated with TNF-a inhibitors. TNF-a functions as a growth factor, induces the formation of proinflammatory cytokines and endothelial adhesion molecules needed for leucocyte accumulation in tissues. TNF-a is essential for the defence against intracellular pathogens and functions as a co-mitogen for T and B cells. ${ }^{8}$

On a molecular level, TNF-a causes the trimerization of TNF- $a$ receptors which activates signal transduction cascades that trigger apoptosis and orchestrate the translocation of the transcription factors $\mathrm{AP}-1$ and NF- $\mathrm{kB}$ to the cell nucleus, as shown in Figure 2. AP-1 and NF- $\mathrm{kB}$ stimulate the transcription of numerous cytokine genes involved in the immune response. ${ }^{8}$

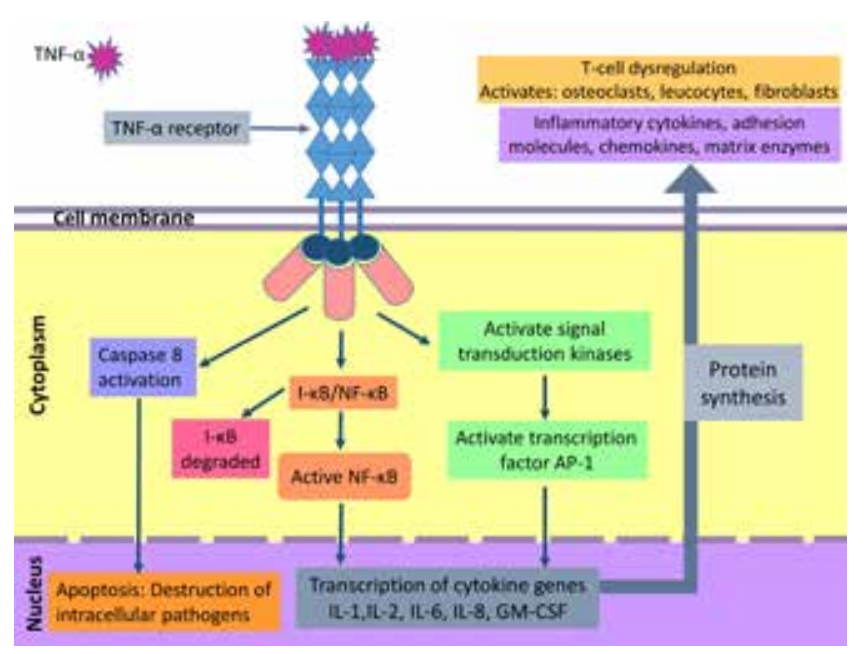

Figure 2. The multiple roles of TNF-a in the immune response. TNF-a forms a trimeric molecule which initiates the trimerization of its receptor molecules. This stimulates signal transduction cascades which result in the translocation of cytoplasmic transcription factors like NF-KB and AP-1 to the nucleus. In the nucleus, this causes the transcription of more inflammatory and pro-inflammatory cytokine genes. It also induces the expression of endothelial adhesion proteins and chemokines in the synovium which attracts leucocytes to the synovium. In addition, activation of the receptor can cause apoptosis in cells harbouring intracellular pathogens.

\section{TNF- $a$ inhibitors}

\section{Etanercept}

Etanercept is a recombinant fusion protein consisting of the TNF-a p75 receptor dimerized on the Fc portion of human $\lg _{1}$. The TNF-a p75 region binds to soluble and membrane bound TNF-a. The presence of mouse amino-acid sequences induces an antibody response that decreases it function, therefore coadministration of methotrexate is desirable.,.$^{2,9}$

Etanercept use is associated with an increased risk for bacterial infections and septic arthritis. Compared to the other TNF-a inhibitors, reactivation of tuberculosis is less frequent with etanercept. The formation of anti-nuclear antibodies has been 
Table 1: TNF-a inhibitors kinetics and indications

\begin{tabular}{|c|c|c|c|}
\hline TNF-a Inhibitor & T1122 (Days) & Dose and interval & Indications \\
\hline Etanercept (Enbrel) & 4.5 & $\begin{array}{l}25 \text { mg twice weekly } \\
\text { or } \\
50 \text { mg once weekly } \\
\text { Subcutaneous }\end{array}$ & $\begin{array}{l}\text { Rheumatoid arthritis, } \\
\text { Psoriasis, } \\
\text { Ankylosing spondylitis, } \\
\text { Juvenile chronic arthritis }\end{array}$ \\
\hline Infliximab (Revellex) & $9-12$ & $\begin{array}{l}\text { 3- } 5 \mathrm{mg} / \mathrm{kg} \text { every } 4-8 \text { weeks } \\
\text { Subcutaneous }\end{array}$ & $\begin{array}{l}\text { Rheumatoid arthritis, } \\
\text { Psoriasis, } \\
\text { Ankylosing spondylitis }\end{array}$ \\
\hline Golimumab (Simponi) & 14 & $\begin{array}{l}50 \mathrm{mg} / \mathrm{month} \\
\text { Subcutaneous }\end{array}$ & $\begin{array}{l}\text { Rheumatoid arthritis, } \\
\text { Psoriatic arthritis, } \\
\text { Ankylosing spondylitis }\end{array}$ \\
\hline Adalimumab (Humira) & $10-12$ & $\begin{array}{l}80 \text { mg loading dose, } \\
\text { thereafter } 40 \text { mg every 14-20 days } \\
\text { Subcutaneous }\end{array}$ & $\begin{array}{l}\text { Rheumatoid arthritis, } \\
\text { Ankylosing spondylitis, } \\
\text { Psoriatic arthritis, } \\
\text { Juvenile idiopathic arthritis, } \\
\text { Plaque psoriasis, } \\
\text { Crohn's disease }\end{array}$ \\
\hline
\end{tabular}

reported with etanercept, but unless active lupus develops, cessation of treatment is not indicated. ${ }^{2,6}$

\section{Infliximab}

Infliximab is an older generation chimeric human/mouse monoclonal antibody and binds soluble and membraneassociated TNF-a receptors. Concurrent administration with methotrexate or glucocorticosteroids reduces formation of antichimeric antibodies and is recommended. ${ }^{2,6}$

\section{Golimumab}

This is a humanized monoclonal antibody reducing the risk of antibody formation and has a high affinity for soluble and membrane bound TNF-a. Adverse effects are associated with the inhibition of TNF-a. It is used in moderate to severe rheumatoid arthritis in adults. ${ }^{2,6}$

\section{Adalimumab}

Adalimumab is a human $\operatorname{lgG}_{1}$ monoclonal antibody to TNF-a. It forms a complex with soluble TNF- $a$ and prevents its interaction with TNFa p55 and p75 cell surface receptors. The use of adalimumab decreases macrophage and T-cell function. ${ }^{2,6}$

\section{Non-TNF-a biological immune modulators}

Currently, four non-TNF-a biological molecules are available to use in the arthritic diseases. Abatacept, rituximab and tocilizumab are used in the management of rheumatoid arthritis. Ustekinumab is a new monoclonal antibody and is active against psoriatic arthritis and psoriasis but not against rheumatoid arthritis. $^{5}$

\section{Abatacept}

Abatacept is a genetically engineered fusion protein consisting of the extracellular domain of cytotoxic T-lymphocyte-associated antigen (CTLA-4) fused to the hinge region of $\operatorname{lgG}_{1}$. The activation of naïve $T$ cells requires the $C D 80 / 86$ costimulatory molecules on dendritic cells to interact with the CD28 molecule on naïve T cells. This interaction is required to complete antigen presentation. Abatacept blocks T-cell costimulation by preventing the binding

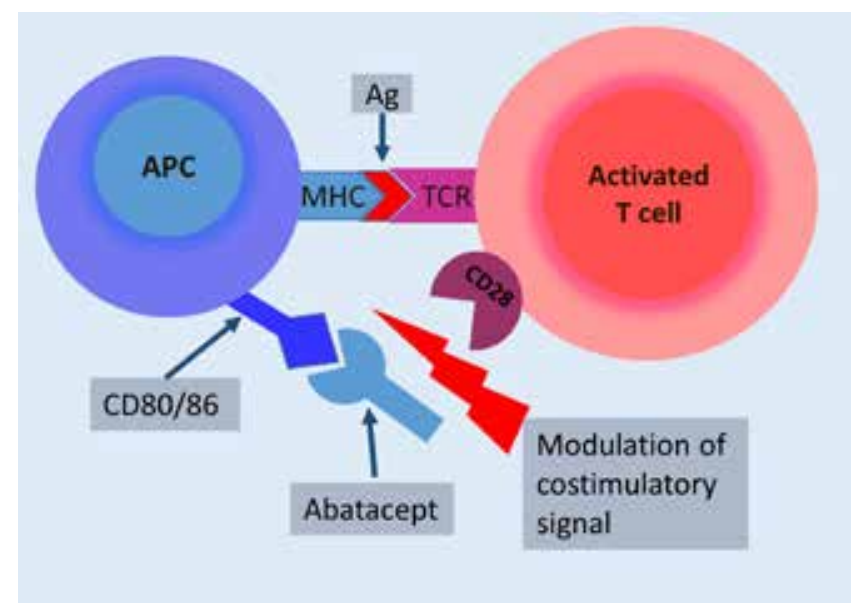

Figure 3. A schematic diagram showing the binding of abatacept to CD80/86 and preventing its interaction with CD28 on naïve T-cells. APC: antigen presenting cell; MHC: major histocompatibility complex, TCR: T-cell receptor, Ag: antigen, CD28: receptor molecule for CD80/86

of $C D 80 / 86$ to $C D 28$ as shown in Figure 3. This decreases the response of naïve $T$ cells to antigen presentation. ${ }^{2,10}$

Abatacept is used in both TNF-a naïve patients and in patients who have previously failed on TNF-a therapy. ${ }^{6,11}$ Concurrent administration with TNF-a inhibitors is discouraged. Abatacept increases the risk for re-activation of latent TB and increases the risk for upper respiratory tract infections. Infusion reactions are rare.

\section{Rituximab}

Rituximab is a chimeric monoclonal antibody to the CD20 receptor found on mature $B$ lymphocytes. Its use leads to the long-lasting near depletion of B cells in the peripheral blood. Rituximab is not used exclusively for the treatment of rheumatoid arthritis but also treat cancers like lymphoma. Rituximab is indicated in rheumatoid arthritis when patients fail to respond to TNF-a inhibitors. ${ }^{12,13}$ Cell mediated and complement dependent cytotoxicity and apoptosis are responsible for the depletion of $B$ lymphocytes. 
Table 2. Summary of the non-TNF-a biological DMARDs, their dosage, primary indications and common and serious adverse effects

\begin{tabular}{|c|c|c|c|}
\hline Immune modulator & Dose and interval & Indications & Adverse effects \\
\hline $\begin{array}{l}\text { Abatacept } \\
\text { (Orencia) }\end{array}$ & $\begin{array}{l}\text { Induction dose: week } 0,2 \text { and } 4 \rightarrow 500 \mathrm{mg} \\
\text { Thereafter } \rightarrow \text { monthly dose: } \\
<60 \mathrm{~kg}: 500 \mathrm{mg} \\
60-100 \mathrm{~kg} 750 \mathrm{mg} \\
>100 \mathrm{~kg}: 1000 \mathrm{mg} \\
\text { Intravenous }\end{array}$ & $\begin{array}{l}\text { Rheumatoid arthritis, Juvenile } \\
\text { idiopathic arthritis }\end{array}$ & $\begin{array}{l}\text { Infusion reactions, } \\
\text { Infections }\end{array}$ \\
\hline $\begin{array}{l}\text { Rituximab } \\
\text { (Mabthera) }\end{array}$ & $\begin{array}{l}\text { Two IV infusions of } 1000 \text { mg two week } \\
\text { interval } \\
\text { Repeat } 6-9 \text { months } \\
\text { Intravenous }\end{array}$ & $\begin{array}{l}\text { Rheumatoid arthritis, } \\
\text { Haematological malignancies, } \\
\text { ANCA associated vasculitis, } \\
\text { Non-Hodgkin's lymphoma, } \\
\text { Chronic lymphocytic lymphoma }\end{array}$ & $\begin{array}{l}\text { Infusion reaction, } \\
\text { Infections, } \\
\text { Reactivation of hepatitis B, } \\
\text { Multifocal leuko-encephalopathy }\end{array}$ \\
\hline $\begin{array}{l}\text { Tocilizumab } \\
\text { (Actemra) }\end{array}$ & $\begin{array}{l}8 \mathrm{mg} \text { every two weeks } \\
\text { Intravenous }\end{array}$ & $\begin{array}{l}\text { Rheumatoid arthritis, } \\
\text { Systemic juvenile idiopathic arthritis, } \\
\text { Juvenile idiopathic arthritis }\end{array}$ & $\begin{array}{l}\text { Infusion reaction, } \\
\text { Infections, } \\
\text { Dyslipidaemia, } \\
\text { Gl perforation }\end{array}$ \\
\hline $\begin{array}{l}\text { Ustekinumab } \\
\text { (Stelara) }\end{array}$ & $\begin{array}{l}45 \mathrm{mg} / 100 \mathrm{~kg} / \mathrm{month} \text { (twice) then } 45 \mathrm{mg} \text { / } \\
100 \mathrm{~kg} \text { every } 12 \text { weeks } \\
\text { Intravenous }\end{array}$ & $\begin{array}{l}\text { Psoriatic arthritis, } \\
\text { Plaque psoriasis, } \\
\text { Crohn's disease }\end{array}$ & $\begin{array}{l}\text { Infections, } \\
\text { Headache, } \\
\text { Pain - pharynx, larynx, } \\
\text { Myalgia, } \\
\text { Exfoliative dermatitis, } \\
\text { Hypersensitivity, } \\
\text { Malignancies }\end{array}$ \\
\hline
\end{tabular}

The high dose of rituximab causes an infusion reaction which can be managed by pre-treatment with a glucocorticosteroid. A skin rash is common with the first treatment but decreases with subsequent treatments. In the case of an urticarial rash or an anaphylactic reaction, the use of rituximab should be discontinued. Rituximab is not associated with the reactivation of TB infections, lymphomas or other tumours. However, the reactivation of hepatitis $B$ is a concern and concomitant antiviral therapy is recommended. Although rare, multifocal leukoencephalopathy is a serious adverse reaction associated with rituximab. ${ }^{14}$

\section{Tocilizumab}

Tocilizumab is a humanized monoclonal antibody that binds to soluble and membrane bound IL- 6 receptors, preventing IL-6 mediated signalling. Interleukin 6 is produced by various immune cells, including macrophages and fibroblasts, and is recognized as an important pro-inflammatory cytokine. IL-6 regulates $\mathrm{T}$-cell function, the acute phase reaction and terminal B-cell differentiation. Binding of IL- 6 causes the recruitment of two molecules of glycoprotein 130 (gp130) to the receptor. ${ }^{15}$ The IL-6 receptor is expressed on hepatocytes and a subpopulation of leucocytes and megakaryocytes. ${ }^{15}$

IL-6 combined with transforming growth factor $\beta$ induces the differentiation of naïve $T$ cells to inflammatory $T h_{17}$ cells. This promotes the maturation of $B$ cells toward the production of IgG. In hepatocytes it stimulates the production of acute phase reactants like $\mathrm{C}$-reactive protein, serum amyloid $\mathrm{A}$, haptoglobin, fibrinogen and a-anti-chymotrypsin. In addition, it decreases the hepatic production of transferrin and hepcidin, contributing to anaemia of chronic inflammation. ${ }^{15}$

Used therapeutically, tocilizumab decreases rheumatoid factor, acute phase reactants and inflammatory $\mathrm{Th}_{17}$ cells, and reduces bone resorption. However, tocilizumab is associated with several adverse drug reactions shown in Table 2 and is not recommended for patients with hepatic disease.

\section{Ustekinumab}

This monoclonal antibody inhibits the function of IL12/IL23 and is registered in South Africa for the treatment of psoriasis. It is effective in treating psoriatic arthritis, psoriasis and Crohn's disease, but has no clinical benefit in rheumatoid arthritis. ${ }^{16}$ Ustekinumab binds to the p40 subunit of both IL-12 and IL-23 and prevents them binding to their respective receptors. IL-12 is produced by macrophages and promotes the Th1 response, activates natural killer cells and together with IL-18 causes interferon- $\gamma$ release. ${ }^{16}$ The failure of ustekinumab in rheumatoid arthritis indicates that these processes are not important in the pathogenesis of rheumatoid arthritis.

\section{Summary of key concepts in the use therapeutic use of biological DMARDs}

- Biological DMARDs are indicated when therapy with small molecule DMARDs fails.

- Biological agents can be used with or without methotrexate, but methotrexate prolongs the therapeutic lifespan of the biological agents.

- TNF-a inhibitors are used before the non-TNF-a inhibitors.

- Tuberculosis infections are common with the TNF-a inhibitors and latent infections can be reactivated.

- It is advisable to vaccinate patients against common infections.

- Opportunistic fungal viral and bacterial infections are common.

- Biological agents do not effect a cure but contribute to achieving a state of remission.

- Withdrawal of biological agents or DMARDs in patients who are in remission causes reactivation of the disease. 


\section{Conclusion}

The target-specific biological agents are clinically useful additions to the DMARDs and improve the chance to achieve remission in patients with rheumatoid arthritis. Their crippling cost, however, limit their use in resource-poor countries. The risk for serious infections in patients on biological DMARDs is of great importance and patients require regular monitoring.

\section{Conflict of interest}

I declare that I have no financial or personal relationship(s) which may have inappropriately influenced me in writing this paper.

\section{References}

1. Singh JA, Saag KG, Louis-Bridges Jr S, et al. 2015 American College of Rheumatology Guideline for the Treatment of Rheumatoid Arthritis. Arthritis Rheumatol. 2016;68:126.

2. Van Vollenhoven RF. Treatment of rheumatoid arthritis: state of the art. Nat. Rev. Rheumatol. 2009;5:531-41.

3. Hazlewood GS, Barnabe C, Tomlinson G, Marshall D, Devoe D, Bombardier C. Methotrexate monotherapy and methotrexate combination therapy with traditional and biologic disease modifying antirheumatic drugs for rheumatoid arthritis: abridged Cochrane systematic review and network meta-analysis. $\mathrm{Br}$ Med J. 2016;353: i1777.

4. Brennan FM, Chantry D, Jackson A, Maini R, Feldman M. Inhibitory effect of TNF-alpha antibodies to synovial cell interleukin -1 production in rheumatoid arthritis. Lancet. 1989;2:244-7.

5. Tarr $\mathrm{G}$, Hogdkinson B, Reuter $\mathrm{H}$. Superheroes in autoimmune warfare: Biologic therapies in current South African practice. S Afr Med J. 2014;104(11):787-91.

6. Scott DL. Biologics-Based Therapy for the Treatment of Rheumatoid Arthritis. Nat Rev Clin Phar Ther. 2012;91(1):30-43.
7. Hernández MV, Meineri M, Sanmartí R. Skin Lesions and Treatment with Tumor Necrosis Factor Alpha Antagonists. Reumatol Clin. 2013;9(1):53-61.

8. Vasanthi $P$, Nalini $G$, Rajasekahr $G$. Role of tumor necrosis factor-alpha in rheumatoid arthritis: a review. APLAR Journal of Rheumatology. 2007;10:270-4.

9. Emery $P$, Breedveld $F C$, Hall $S$, et al. Comparison of methotrexate monotherapy with a combination of methotrexate and etanercept in active, early moderate to severe rheumatoid arthritis (COMET): a randomised, double blind, parallel treatment trial. Lancet. 2008;372:375-82.

10. Kremer JM, Westhovens $R$, Leon $M$, et al. Treatment of rheumatoid arthritis by selective inhibition of T-cell activation with fusion protein CTLA4lg. N. Engl. J. Med. 2003;349:1907-15

11. Genovese MC, Becker JC, Schiff M, et al. Abatacept for rheumatoid arthritis refractory to tumor necrosis factor alpha inhibition. N. Engl J Med. 2005;353(11):1114-23.

12. Emery P, Fleischmann R, Filipowicz-Sosnowska A, et al. The efficacy and safety of rituximab in patients with active rheumatoid arthritis despite methotrexate treatment: results of a phase IIB randomized, double-blind, placebo-controlled, dose-ranging trial. Arthritis Rheum. 2006;54:1390-1400.

13. Cohen SB, Emery P, Greenwald MW, et al. Rituximab for rheumatoid arthritis refractory to anti-tumor necrosis factor therapy: results of a multicenter, randomized, double-blind, placebo-controlled, phase III trial evaluating primary efficacy and safety at twenty four weeks. Arthritis Rheum. 2006;5:2793-2806.

14. Clifford DB, Ances B, Costello $C$, et al. Rituximab associated progressive multifocal leukoencephalopathy in rheumatoid arthritis. Arch. Neur. 2011; 68:1156-64.

15. Scheller J, Garbers C, Rose-John S. Interleukin-6: from basic biology to selective blockade of pro-inflammatory activities. Semin Immunol. 2014;26(1):2-12.

16. Gottlieb A, Menter A, Mendelsohn A, et al. Ustekinumab, a human interleukin 12/23 monoclonal antibody, for psoriatic arthritis: randomised, double-blind, placebo-controlled, crossover trial. Lancet. 2009;373:63340. 